Annals of Plant Sciences

\title{
Micropropagation of traditional medicinal plant Ceropegia juncea
}

\section{Binish T.}

Department of Botany, Adhiyaman Arts and Science College for Women, Uthangarai, Krishnagiri Dt, Tamilnadu, India.

Received: 12/24/2017; Revised: 12/29/2017; Accepted: 1/15/2018

\begin{abstract}
Ceropegia species which possess wide medicinal properties are being used in different traditional medicinal systems that are used by tribal people for curing different ailments. Ceropegia juncea was reported to be the source of 'Soma', a plant drug of the Ayurvedic system of medicine. The plant extract is used for the treatment of antiinflammatory, analgesic, antiulcer activities, liver disorders, hypotension, ulcerative condition and fever. It is also used as typical anesthetic agent. The present study was conducted to establish a protocol for in- vitro propagation of an endemic medicinal plant Ceropegia juncea maximum shoot proliferation better shoots with a sprouting frequency of $86 \%$ and with an average of $8.28 \pm 1.11$ shoots /explants and attained a length of $5.37 \pm 0.74 \mathrm{~cm}$ was achieved on Murashige and Skoog's, 1962 (MS) medium supplemented with 6-benzylaminopurine (BAP) $1.5 \mathrm{mg} / \mathrm{L}+\mathrm{NAA}$ $1.0 \mathrm{mg} / \mathrm{L}$ and highest rooting of in vitro derived shoots was achieved on half MS with IBA $0.75 \mathrm{mg} / \mathrm{L}$.
\end{abstract}

Keywords: In vitro; Ceropegia juncea

\section{Introduction}

The genus Ceropegia L. belongs to the sub-family Asclepiadoideae under the family Apocynaceae in APG III Classification. Ceropegia species are being used traditionally, due to their immense therapeutic potential to treat as well as to cure various diseases. In the fields of Ayurvedic drug preparation Ceropegia tubers are used as nutritive tonic and blood purifier (Jagtap and Singh, 1999). "Cerpegin" is a key compound of the genus Ceropegia. Sukumar et al., (1995) revealed that the edible species of Ceropegia juncea contains steroids, polyphenols, sugars and potassium. This extract is used to cure kidney stone and urinary tract disorders (Paras et al., 2011). Pavan Kumar et al., (2012) focused on the phytochemical profile of the plant Ceropegia juncea constituents of alkaloids, tannins, sterols, glycosides, saponins, proteins, lipids and carbohydrates. The hydro-alcoholic extract of Ceropegia juncea whole plant possesses hepatoprotective activity against paracetamol induced hepatic damage and found it to have significant antioxidant activity in rats. Ceropegia species has enormous medicinal value, but the genus Ceropegia has now been added to the list of Indian endangered plants. Propagation through seed hampered due to its low viability rate, poor germination and scanty rooting of seedlings. Vegetative propagation by root tubers and stem cuttings is very arduous. The rapid deforestation hampers its natural regeneration potential in a big way therefore; large scale propagation has become a prerequisite for effective conservation of this endangered species.

\section{${ }^{*}$ Corresponding Author:}

Binish T.

Department of Botany,

Adhiyaman Arts and Science College for Women,

Uthangarai, Krishnagiri Dt., Tamilnadu, India.

E-mail: vinutpm@gmail.com

\section{Materials and Methods}

Micropropagation studies

Ceropegia juncea was collected from Marthuvalmalai hills, a part of the Southern Western Ghats, during rainy season. The collected plant was identified by using Flora of Eastern Ghats (Pullaiah et al., 2011). The collected plant parts such as node, internode and shoot tips were used for micropropagation. Murashige and Skoog's (1962) medium was found to be the most commonly used medium for the propagation of Ceropegia as per the existing literature. Therefore, all trials were later on carried out on MS medium. However, use of full strength salt formulations with media supplements yielded poor roots results to the reduced salt strength i.e. half salt strength.

The plantlets were transferred to seven-centimeter diameter plastic cups containing different types of hardening materials. One of the hardening materials like equal ratio of sterilized soil, coir waste and Azolla (1:1:1). Others filled with potting mixture of cow dung, autoclaved river sand and garden soil (1:1:1). The individual plantlets were covered with polythene membrane to maintain humidity; small holes were made, and watered every two days with half strength MS solution free of sucrose. After twenty days, the polythene membrane was removed and plants were allowed to adjust to ambient conditions. Then the hardened plants were transferred to earthen pots and kept under shade not exposing to direct sunlight. The acclimatized plants were finally transferred to soil.Each experiment consisted of five to seven replicate per plant growth regulator treatment. The differences in 
root and shoot length among the micropropagated Ceropegia species with different concentration of hormones were calculated with Tukeys test.

\section{Results}

Effect of BAP on shoot apices of Ceropegia juncea

Nodal explants and shoot tip portion obtained from the mature plants were cultured on MS medium. The nodes remained green and fresh but failed to sprout on MS media without cytokinins. BAP was found to be the most efficient cytokinin for the axillary bud initiation and subsequent proliferation. MS medium supplemented with different concentrations of BAP were tested for shoot proliferation. Microshoots were proliferated on MS medium containing the best concentration of BAP $(1.5 \mathrm{mg} / \mathrm{L})$. Sub-culture on the MS medium containing different concentrations of BAP, microshoots were observed and they measured twice. The sub-cultured microshoots and node, produced adventitious buds on the third day in MS medium containing BAP $1.5 \mathrm{mg} / \mathrm{L}$ were found to have grown faster. New shoots developed adjacent to the axillary shoots and had grown well within fifteen days. Shoot multiplication rate was evaluated after two weeks BAP $1.5 \mathrm{mg} / \mathrm{L}$ and proved to be most effective, as in this medium produced better shoots with a sprouting frequency of $86 \%$ and with an average of $8.28 \pm 1.11$ shoots / explants and attained a length of $5.37 \pm 0.74 \mathrm{~cm}$.

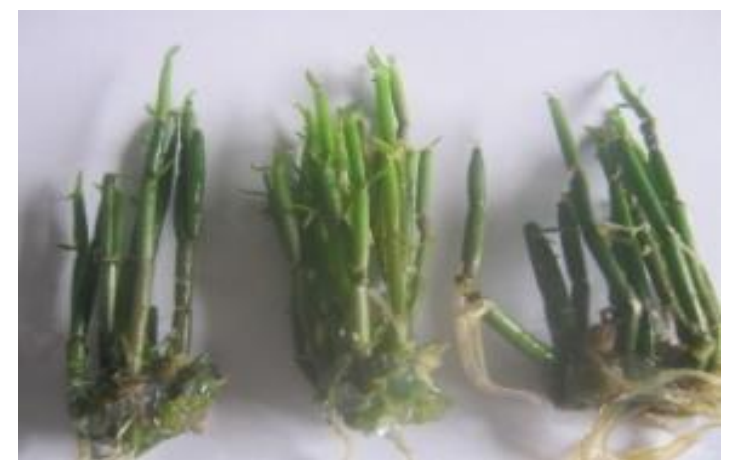

Plate 1. Combined effect of BAP and NAA in shoot regeneration of $C$. juncea

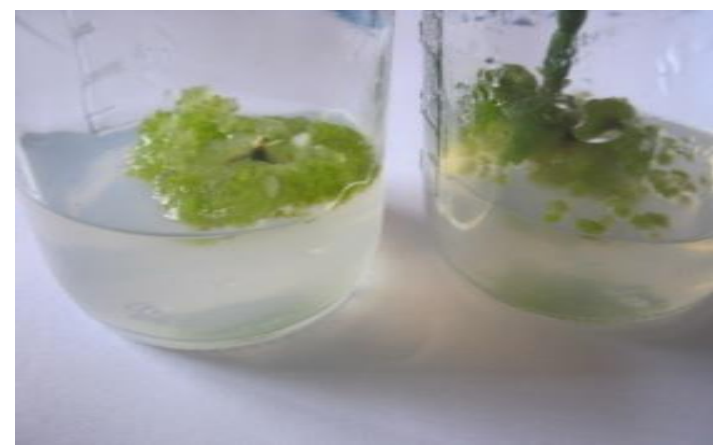

Plate 2. Ceropegia juncea - Callus formation and multiplication

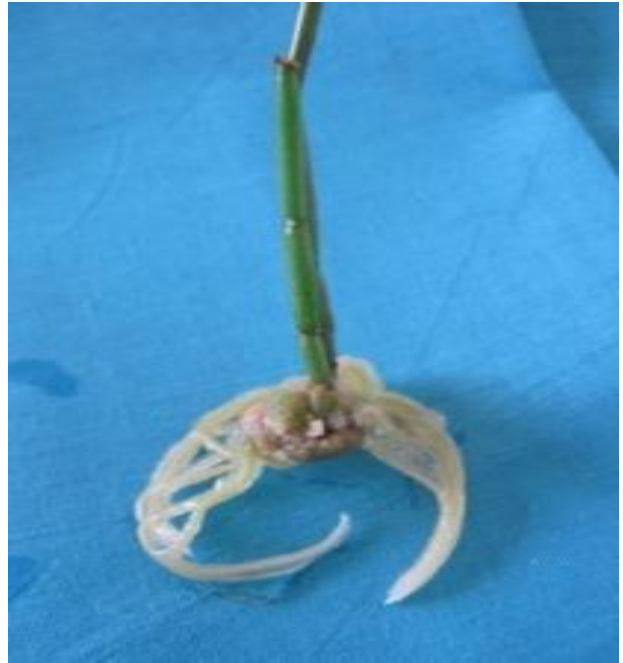

Plate 3. In vitro roots of C. juncea

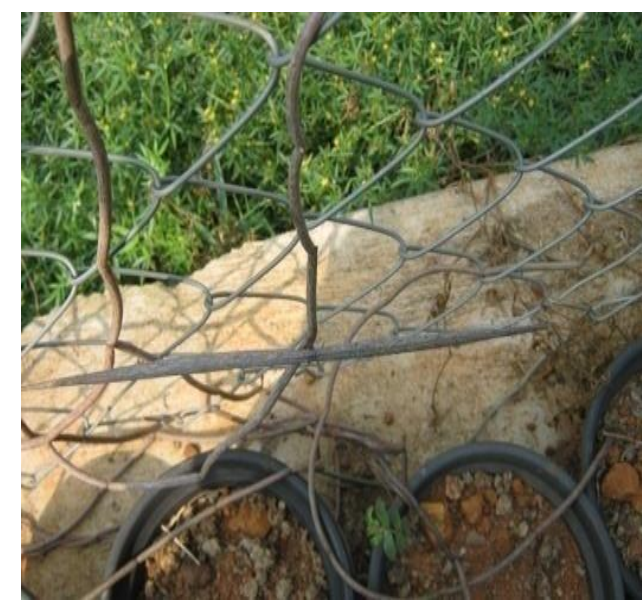

Plate 4. C. juncea-Hardened plants

Shoot multiplication was observed on all the combinations of BAP with $\mathrm{KN}, \mathrm{NAA}$, IAA and IBA, highest number of shoots was observed in third sub-culture on MS medium supplemented with BAP $1.5 \mathrm{mg} / \mathrm{L}+\mathrm{NAA} 1.0 \mathrm{mg} / \mathrm{L}(9.71 \pm 0.75)$ shoots/explants with $76 \%$ response. The results are reported in table 1 . The developed shoots were healthy, strong and elongated. Creation of roots was inhibited by the content of this concentration. On the other hand, auxin had a stimulating influence on the creation of roots (Plate 1).

\section{Callus induction from nodal explants of Ceropegia juncea}

Pale green friable callus was observed the internodes of Ceropegia juncea on MS medium augmented with NAA within nine days of the third sub-culture. Higher percentage $(80 \%)$ of node callus formation was observed on the medium augmented with a hormonal combination of BAP $(1.5 \mathrm{mg} / \mathrm{L})+$ NAA (2mg/L) (Plate 2: A \& B). These calli were relatively friable and yellowish green in color. 
Table 1. Effect of different combination of plant growth regulators in shoot regeneration from nodal explant of Ceropegia juncea cultured on MS medium with 3\% sucrose.

\begin{tabular}{|c|c|c|c|c|c|c|c|}
\hline BAP & NAA & IAA & IBA & $\begin{array}{l}\text { Shoot } \\
\text { induction } \\
(\%)\end{array}$ & $\begin{array}{l}\text { Number of multiple } \\
\text { shoots/explant } \pm \text { SD }\end{array}$ & $\begin{array}{l}\text { Average length of } \\
\text { shoots/explant } \pm \text { SD } \\
(\mathrm{cm})\end{array}$ & $\begin{array}{l}\text { Shoots with } \\
\text { basal callus }\end{array}$ \\
\hline 1.5 & & & & $70 \%$ & $7.85 \pm 1.06^{\mathrm{fg}}$ & $7.01 \pm 0.64^{\mathrm{cd}}$ & + \\
\hline 1.5 & $\begin{array}{l}0.5 \\
10\end{array}$ & & & $76 \%$ & $9.71 \pm 0.75^{\mathrm{gh}}$ & $5.31 \pm 0.55^{c}$ & + \\
\hline 1.5 & $\begin{array}{l}1.0 \\
1.5\end{array}$ & & & $50 \%$ & $5.14 \pm 0.69^{\text {cde }}$ & $5.01 \pm 0.12 b^{c}$ & ++ \\
\hline 1.5 & $\begin{array}{l}1.5 \\
20\end{array}$ & & & $80 \%$ & $\mathrm{CP}$ & $\mathrm{CP}$ & +++ \\
\hline 1.5 & 2.0 & & & $70 \%$ & $\mathrm{CP}$ & $\mathrm{CP}$ & ++ \\
\hline 1.5 & 2.5 & 0.5 & & $70 \%$ & $1.57 \pm 0.78^{\mathrm{ab}}$ & $1.82 \pm 0.73^{\mathrm{a}}$ & + \\
\hline 1.5 & & 1.0 & & $40 \%$ & $1.14 \pm 0.37^{\mathrm{a}}$ & $1.25 \pm 0.35^{\mathrm{a}}$ & ++ \\
\hline 1.5 & & & 0.5 & $60 \%$ & $1.85 \pm 1.21^{\mathrm{ab}}$ & $3.84 \pm 0.36^{\mathrm{ab}}$ & - \\
\hline 1.5 & & & 1.0 & $80 \%$ & $1.28 \pm 0.48^{\mathrm{a}}$ & $3.42 \pm 0.40^{\mathrm{b}}$ & - \\
\hline
\end{tabular}

(Tukey's HSD test, $\mathrm{P}<0.005)$; (-) sign indicates no callusing, number of $(+)$ sign represents the intensity of callusing; $\mathrm{CP}$ - callus production.

Table 2. Effect of different auxins on root response of Ceropegia juncea microshoots cultured on half MS medium after third sub-culture.

\begin{tabular}{|c|c|c|c|c|}
\hline Auxins & $\begin{array}{c}\text { Concentration } \\
(\mathrm{mg} / \mathrm{L})\end{array}$ & $\begin{array}{l}\text { Days for root } \\
\text { induction }\end{array}$ & $\begin{array}{l}\text { Average number of root/ } \\
\text { explant } \pm \text { SD }\end{array}$ & $\begin{array}{c}\text { Average length of roots/ explant } \pm \\
\text { SD }(\mathrm{cm})\end{array}$ \\
\hline \multirow{4}{*}{ IAA } & 0.25 & $10-14$ & $3.20 \pm 0.44^{\mathrm{b}}$ & $4.42 \pm 0.20^{\mathrm{ab}}$ \\
\hline & 0.5 & $10-14$ & $3.60 \pm 0.54^{\mathrm{ab}}$ & $5.06 \pm 0.52^{\mathrm{bc}}$ \\
\hline & 0.75 & $10-14$ & $5.20 \pm 0.83^{\mathrm{bc}}$ & $5.44 \pm 0.35^{\mathrm{bc}}$ \\
\hline & 1.0 & $10-14$ & $5.20 \pm 0.44 \mathrm{bc}$ & $5.94 \pm 0.15 b^{c d}$ \\
\hline \multirow{5}{*}{ IBA } & 1.25 & $10-14$ & $3.80 \pm 0.44^{\mathrm{ab}}$ & $4.42 \pm 0.17^{\mathrm{ab}}$ \\
\hline & 0.25 & $5-14$ & $4.60 \pm 0.89^{\mathrm{bc}}$ & $5.52 \pm 0.26^{\mathrm{bc}}$ \\
\hline & 0.5 & $5-14$ & $5.60 \pm 0.54 \mathrm{~cd}$ & $5.82 \pm 0.44^{\mathrm{bc}}$ \\
\hline & 0.75 & $5-14$ & $6.20 \pm 0.44 \mathrm{~cd}$ & $5.96 \pm 0.59 \mathrm{c}$ \\
\hline & 1.0 & $5-14$ & $6.60 \pm 0.54^{\mathrm{d}}$ & $4.16 \pm 0.11^{\mathrm{b}}$ \\
\hline \multirow{5}{*}{ NAA } & 1.25 & $5-14$ & $4.40 \pm 0.54^{\mathrm{b}}$ & $3.42 \pm 0.22^{\mathrm{a}}$ \\
\hline & 0.25 & $9-14$ & $2.60 \pm 0.89^{a}$ & $6.12 \pm 0.19^{\mathrm{bd}}$ \\
\hline & 0.5 & $9-14$ & $3.60 \pm 0.54^{\mathrm{ab}}$ & $5.88 \pm 0.41^{\mathrm{bc}}$ \\
\hline & 0.75 & $9-14$ & $2.40 \pm 0.54^{a}$ & $5.28 \pm 0.25^{\mathrm{abc}}$ \\
\hline & 1.0 & $9-14$ & NR & NR \\
\hline
\end{tabular}

Root induction from microshoots of Ceropegia juncea

Root initiation was noticed within two week of culture and the data was recorded. After fifth day of incubation, rooting was observed and measured. Shoot inoculation on half strength MS medium supplemented with IAA (0.25-1.25 $\mathrm{mg} / \mathrm{L})$, improved the percentage of rooting up to 1.0 $\mathrm{mg} / \mathrm{L}$, along with maximum number of micro roots/shoots (4-5). Auxin promotes growth of roots only at extremely low concentrations. At higher concentrations, it always inhibits growth of root.Shoots kept on MS medium fortified with IBA $(0.75 \mathrm{mg} / \mathrm{L})$ showed quick responses (5-14 days) 6 thick, long roots were observed (Plate 3).

Acclimatization and transplantation of plantlets The regenerated plantlets were removed from the culture medium and washed with tap water. Rooted shoots were removed from the medium and they were transplanted in plastic cups with a mixture of different manures. Among the in vitro plantlets, 50\% plants were hardened with a bio-fertilizer Azolla along with sterilized soil and coir waste (1:1:1) 50\% plantlets with potting mixture of cow dung, autoclaved river sand and garden soil (1:1:1). The comparison was made between the plants transferred to different mixtures on the basis of their survival percentage and plant development. Plantlets were kept for 10-15 days in high humidity and low light intensities. The humidity is gradually decreased to the ambient level over a period of 1530 days and the light intensity is also gradually increased. Plants were irrigated initially with $1 / 4$ strength MS solution and afterwards whenever required with the tap water. The plantlets were acclimatized in hardening chamber for one month and subsequently transferred to the earthen pots and maintained under shade for one more week. Then, plants were exposed to sunlight for a few hours and then for a week. After two weeks of hardening, their response was recorded. Among the two different manures cow dung, autoclaved river sand and garden soil were tested to find out the best hardening medium. Afterwards, plants were transferred to soil and watered with tap water. The hardened plants produced well shoots, simultaneously produced flowers and follicles are representing in Plate 4. Tissue culture technique used for propagation may prove useful tool for the multiplication of Ceropegia juncea facilitate the bulking up of material for experimental purpose mentioned above without over harvesting the species from natural habitat from the point of view of its conservation also. 


\section{Discussion and Concluction}

In vitro techniques used for conserving wild and endemic species of Ceropegia by mass multiplication for subsequent reintroduction in their natural habitat (Patil, 1998). Axillary bud proliferation is considered the most simple and reliable method for the establishment of elite clones the potential to develop into complete plantlets (Gangaprasad et al., 2005; Ugraiah et al., 2011). Superiority of BAP for shoot multiplication in Apocynaceae has been reported in many studies (Martin, 2002; Ramulu et al., 2002; Britto et al., 2003; Karuppusamy et al., 2009). BAP in combination with auxins NAA was required in optimal quantity for shoot multiplication in Ceropegia juncea. These results were in corroborative with the findings on Gymnema sylvestre, where BAP $(5 \mathrm{mg} / \mathrm{L})$ in combination with NAA $(0.2 \mathrm{mg} / \mathrm{L})$ is reported to induce maximum number of shoots along with callus production at the base of the proliferated shoots Reddy et al., (1998). The same combination which was also found suitable for in vitro raising of several valuable medicinal plants (Kim et al., 2003; Khosravi et al., 2007; Catapan et al., 2009; Pillai et al., 2009; Tyagi et al., 2010; Kumar et al., 2012). The present study higher frequency of rooting was reported when MS medium with IBA $(1.0 \mathrm{mg} / \mathrm{L})$ on Ceropegia juncea and IBA $(1.5 \mathrm{mg} / \mathrm{L})$. Similarly IBA was rooting hormone in many medicinal plants such as Dalbergia sissoo (Pradhan et al., 1998), Ceropegia bulbosa and Ceropegia bulbosa var. lushii (Patil, 1998), Decalepis arayalpathra (Gangaprasad et al., 2005), Caralluma edulis (Rathore et al., 2008), Ceropegia intermedia (Karuppusamy et al., 2009) and Ceropegia fantastica (Chandore et al., 2010). The plantlets were successfully established in soil with $80 \%$ survival.

\section{References}

1. Britto SJ, Natarajan E and Arockiasamy DI. In vitro flowering and shoot multiplication from nodal explants of Ceropegia bulbosa Roxb. var. bulbosa. Taiwania, 48.2 (2003) pp. 106-111.

2. Catapan E, Moreno FN, Silva ML, Otuki MF, Niero R, Filho VC, Yermes RA and Viana AM. Protocols for In vitro Culture and Phytochemical Analysis of Phyllanthus species (Euphorbiaceae), Journal of Biomedicine and Life Science, 547.1 (2009) pp.167-177.

3. Chandore AN, Nimbalkar MS, Gurav RV, Bapat VA and Yadav SR. An efficient micropropagation protocol for multiplication and restoration of Ceropegia fantastica Sedgw.: a critically endangered plant species. Current Science 99 (2010) pp. 1593-1596.

4. Gangaprasad A, Decruse SW, Seeni S and Nair GM. Micropropagation of ecorestoration of Decalepis arayalpathra (Joseph and Chandra) Venter- An endemic and endangered ethnomedicinal Plant of Western Ghats. Indian Journal of Biotechnology, 4 (2005) pp. 265-270.
5. Jagtap A P and Singh N P. Fascicles of flora of India (Botanical Survey of India) Kolkatta (1999) pp. 211 241.

6. Karuppusamy S, Kiranmai C, Aruna V and Pullaiah T. In vitro conservation of Ceropegia intermedia -An endemic plant of South India. African Journal of Biotechnology 8.17 (2009) pp. 4052-4057.

7. Khosravi P, Maryam J K., Gorban A N. and Bihamta M R. A protocol for mass production of Rosa bybrid cv. Iceberg through in vitro propagation. Iranian Journal of Biotechnology 5 (2007) pp. 100-104.

8. Kim C K., Oh J Y, Jee So and Chung J D. In vitro micropropagation of Rosa hybrid L. Plant Biotechnology 5 (2003) pp. 115-119.

9. Kumar S R S, Krishna V, Venkatesh, Pradeepa K, Kumar K G and Gnanesh AU. Direct and indirect method of plant regeneration from root explants of Caesalpinia banduc (L) Roxb. A threatened medicinal plant of Western Ghats. Indian Journal of Experimental Biology 50 (2012) pp. 910-917.

10. Martin K P. Rapid propagation of Holostemma adakodium, a rare medicinal plant. Plant Cell Tissue Organ Culture 72 (2002) pp. 79-82.

11. Murashige T and Skoog F. A revised medium from rapid growth and bioassays with tobacco tissue cultures. Plant Physiology 15.3 (1962) pp. 473-497.

12. Paras S, Mehta SC, Gargee D, Lakshmayya B, Sunil K. Gastroprotective and antioxidant activities of Ceropegia juncea leaf ethanol extract. Der Pharmacia Sinica, 2.4 (2011)pp. 99-107.

13. Patil VM. Micropropagation of Ceropegia spp. In vitro cellular Developmental Biology- Plant 34 (1998) pp. 240243.

14. Pavankumar VSPN, Vrushabendra Swamy BM, Vishwanath KM and Raja Sekhar VSP. Antioxidant and Hepatoprotective potential of Ceropegia juncea Roxb in Paracetamol induced hepatotoxicity in rats. Research Journal of Pharmacentical Biological and Chemical Science 3.1(2012) pp. 930-944.

15. Pillai Geetha S, Raghu A V, Martin G, George S. and Balachandran I. In vitro Propagation of two tuberous Medicinal plants: Holostemma ada - kodiea and Ipomoea mauritiana. Journal of Biomedicine and Life Seience, 547.1 (2009) pp. 81-92.

16. Pradhan C, Kar S, Pattnaik S. and Chand P K. Propagation of Dalbergia sissoo Roxb. Through In vitro shoot proliferation from cotyledonary nodes. Plant Cell Reports 18 (1998) pp. 122-126.

17. Pullaiah T, Sandhya Rani S and Karuppusamy S. Flora of Eastern Ghats, vol.4. Regency publications Delhi. (2011) pp. 99.

18. Ramulu R D, Murthy K S R., Pullaiah T. In vitro Propagation of Cynanchum calliatum. Journal of Tropical Medicinal Plants 3 (2002) pp. 233-238. 
19. Rathore M S, Dagla H R., Singh M and Shekhawat N S. Rational development of in vitro methods for conservation, propagation and characterization of Caralluma edulis. World Journal of Agricultural Science, 4.1 (2008) pp. 121-124.

20. Reddy P S, Gopal G R., Sita G L. In vitro multiplication of Gymnema sylvestre R. Br. An important medicinal plant. Current Science, 75 (1998) pp. 843-845.

21. Sukumar E, Gopal H and Rao RB. Pharmacological actions of cerpegin, a novel pyridine alkaloid from Ceropegia juncea. Fitoterapia, 66 (1995) pp. 403-406.

22. Tyagi $\mathrm{P}$, Khanduja $\mathrm{S}$ and Kothari S L. In vitro Culture of Capparis deciduas and assessment of clonal fidelity of the regenerated plants. Journal of Biologia Plantarum 54.1 (2010) pp. 126-130.

23. Ugraiah A, Raja Sreelatha V, Krishna Reddy P V, Rajasekhar K., Sandhya Rani S, Karuppusamy S and Pullaiah T. In vitro shoot multiplication and conservation of Caralluma bbupenderiana Sarkaria-an endangered medicinal plant from South India. African Journal of Biotechnology 10.46 (2011) pp. 9328 9336.

\section{Cite this article as:}

Binish T. Micropropagation of traditional medicinal plant Ceropegia juncea. Annals of Plant Sciences 7.2 (2018) pp. 1992-1996.

do $\mathrm{http://dx.doi.org/10.21746/aps.2018.7.2.2}$

Source of support: Nil

Conflict of interest: Nil 